\title{
Starving Srebrenica and the Recipes for Survival in the Bosnian War (1992-1995)
}

\author{
Markéta Slavková
}

DOI: 10.21104/CL.2019.3.02

\begin{abstract}
This article discusses the topic of food scarcity, hunger, and survival strategies in the context of the 1992-1995 Bosnian War. I open up the question of the role of food in the armed conflict using prevailingly the example of Srebrenica (and partially Sarajevo) in Bosnia and Herzegovina, where I have undertaken long-term ethnographic fieldwork between 2013-2018. I argue that the people concentrated in the UN 'Safe Area' of Srebrenica were intentionally subjected to mass starvation prior to the genocide. One of the most commonly adopted strategies against the food insecurity was food self-provisioning. In particular, I focus on the everyday strategies that emerged during the armed conflict with a focus on humanitarian aid and the consumption of wild and semi-wild plants. I am trying to show that the bio-cultural knowledge of food and food self-sufficiency play an important role in increasing the individual survival chance in times of overall material scarcity and starvation.
\end{abstract}

Key words

anthropology of food, food self-provisioning, social change, war in Bosnia and Herzegovina in 1990 s, Srebrenica

\section{Acknowledgment}

This work was supported by the Slovak Research and Development Agency under the contract No. APVV-14-0431.

\section{Contact}

Mgr. Markéta Slavková, Ph.D., Etnologický ústav AV ČR, v. v. i., Na Florenci 1420/3, 11000 Praha 1, Czech Republic; e-mail: slavkova@eu.cas.cz.

\section{Jak citovat / How to cite}

Slavková, Markéta. (2019). Starving Srebrenica and the Recipes for Survival in the Bosnian War (1992-1995). Český lid 106, 297-316. doi:http://dx.doi. org/10.21104/CL.2019.3.02 


\section{Introduction}

In this article, I open the topic of food scarcity, hunger and survival strategies in the context of the war in Bosnia and Herzegovina between 1992-1995. ${ }^{1}$ These findings are a result of my $\mathrm{PhD}$ dissertation ethnographic research in Srebrenica and Sarajevo, Bosnia and Herzegovina and subsequent project work for the Comenius University in Bratislava between 2013-2018. I base my research prevailingly in the discipline of social anthropology with an emphasis on ethnographic fieldwork as the key research method.

I attempt to illustrate how people trapped in the UN 'Safe Area'2 of Srebrenica dealt with food scarcity with a special focus on survival strategies. I examine discourses of hunger as well as the actual embodiment of hunger. Moreover, I intend to show that the populations targeted on the basis of their prescribed identity were being starved out prior to the Srebrenica genocide. ${ }^{3}$ In the centre of my attention is the question how the affected groups and individuals dealt with the overall material scarcity in order to survive.

It is a universally known fact that strategies of food provisioning in armed conflicts become the biggest issue (e.g. Collingham 2012; Redžić 2010). Redžić (2010), amongst others, points out that war leads to shortages of food, water and medical supplies, and therefore generates undernourishment as well as acute and chronic hunger. This is mainly due to the destabilization of the food production systems that commonly comes about during armed conflicts. Moreover, as Collinson and Macbeth (2014) argue, an armed conflict between groups of people often leads to disruption in the prevailing social order and transforms social and economic patterns of everyday life. This clearly shows in the case of Srebrenica. In order to ensure food security for the population of a town or a city throughout all seasons of the year, a developed agricultural system is necessary.

Mintz has pointed out that the major changes in consumption habits are usually brought on by major disruptions in ordinary routines (Mintz 1995;

1 The manuscript is based on my PhD dissertation: Cooking and Dining in Times of War and Peace: Changing Contexts and Modes of Food Production, Preparation and Consumption in Srebrenica, Bosnia and Herzegovina.

2 I intentionally write the appellation 'safe area' in quotation marks to emphasise that these areas were certainly not 'safe' under the UN protection, which is more than apparent in the case of Srebrenica.

3 Based on my research finding I conclude that what happened in Srebrenica can be categorised as an act of genocide and, thus, I support in this sense the verdict of the ICTY (International Criminal Tribunal for the Former Yugoslavia in the Hague). 
Messer 1997). Extreme food shortages usually lead to loosening up of the generally practiced food exclusions (Messer 1997; Redžić 2010; Redžić Barudanović - Pilipović 2010; Jug-Dujaković - Łuczaj 2016; Vorstenbosch - de Zwarte - Duistermaat - van Andel 2017). This was also the case of Srebrenica. Disruptions of ordinary routines appeared in many aspects of the everyday life. The town was besieged, the industrial food production collapsed, there was no humanitarian aid coming to the area during the first year of the conflict and the demographic situation has drastically changed. One of the most important causes of food scarcity was precisely the fact that the town was besieged by the armies of JNA (Jugoslavenska narodna armija/Yugoslav National Army), later the VRS (Vojska Republike Srpske/ Bosnian Serb Army) and other paramilitary groups. Srebrenica did not become an enclave overnight. This situation had been slowly developing even before the war had started 'officially' on April 6, 1992.

Even though the territory controlled by the Srebrenica militias was enlarged during 1992, it was still impossible to produce or to import enough food that would be able to feed the people in the enclave. Halilovich states that 'the town has swollen' with refugees from the Podrinje region as the Serb-controlled military progressed (Halilovich 2015: 37-38). Halilovich states that the population rose from the town's original 6,000 to 40,000 people (ibidem: 38). It is important to note that the vast majority of the people in the enclave according to my information were civilians.

Moreover, as Nuhanović states, many of the people who sought refuge in the area had not known each other prior to the war, a fact which united the remaining local population, so for those displaced it was harder to survive (Nuhanović 2007: 87). Here, it is important to point out again that the vast majority of these people were civilians, even though many of them were adult men. They did not have a professional army training (except the compulsory basic training they had been through when on national service during the existence of the SFRJ - Socijalistička Federationa Republika fugoslavija/Socialist Federative Republic of Yugoslavia) and certainly they did not have any proper military equipment to speak of. Then there were the women, the children and the elderly. The only exceptions were a few groups of self-organised militia that I mention below in the text, however, their numbers were minimal in comparison to the rest.

In this general introduction, I tried to point out that war creates many difficulties on an everyday level when it comes to food production. In the following subsections, I am going to look in greater detail into the everyday lives of the affected inhabitants using the example of food, which is the main interest of this article. First, I will look into the subsistence strategies of the civilians, later I will elaborate on other strategies, including scaven- 
ging food from the surrounding countryside, which occasionally meant even food raids if the scavengers were armed. Last but not least, I am also going to discuss international humanitarian aid and especially its inability to improve the situation in the area. Thus, the reader can gain insight into the everyday diet of the hungry people, who were trapped in the Siege of Srebrenica, and learn about the 'tastes' of war.

\section{Food in the Bosnian War in the 1990s and recipes for survival}

At the beginning of the last war food production industry in the Srebrenica area collapsed and people trapped in the enclave had to come up with new strategies of obtaining food. They depended on a few limited options. It was impossible to have any sustainable food production for several reasons: 1) the population trapped in the enclave did not have access to any farm land, as Srebrenica is located in a valley in between steep hills; 2) the production of food in the small gardens was not sustainable because of shelling - the crop would be either destroyed by explosions or else, most likely, stolen by the masses of hungry people, however people try to grow vegetables and tobacco both in Srebrenica and Sarajevo in flower pots. Only the people that remained in the villages in the countryside had access to agricultural production and therefore they were generally better off food-wise than the ones trapped in the enclave. The villages were also the places where the people living in the enclave tried to obtain food - an activity that was carried out in multiple ways.

Emir Suljagić, one of Srebrenica's well-known survivors, describes the lack of food in his book Razglednica iz groba ${ }^{4}$ (2005). He says that by July 1992 the people in the enclave ate once or rarely twice a day and were exhausted (Suljagić 2005: 38). Three meals per day were the privilege of the war profiteers (ibidem: 38 ). The long-term starvation caused painful spasms in their hungry stomachs (ibidem: 39). Suljagić and a young man who had spent the war in Goražde came to the conclusion that their caloric intake during the Bosnian War was smaller than that of the captives of Stalin's gulags (ibidem: 39).

Suljagić's statement could be further supported by findings of Redžić, Barudanović and Pilipović (2010) made in the Podrinje area. Even though this research was carried out after the war, Redžić had also conducted some research in Sarajevo during the war and had experienced life under the siege in person. Refugees from Podrinje who fled to Sarajevo were amongst his research participants (Redžić 2010). In the case of Podrinje, Redžić et al. estimate that

4 In English A Postcard from the Grave. 
during the initial months of the war, people lost up to $30 \mathrm{~kg}$ in some cases which clearly shows the extent of the mass undernourishment (Redžić - Barudanović - Pilipović 2010: 176). Many of my research participants described that they observed changes in their behaviour and the ability to think. As some of them claim, their main driving force was 'the desire to survive'.

Drawing on Redžićs's wartime research (1993), Redžić et al. argue that the general reaction to the new conditions was to obtain food from the surrounding countryside (Redžić - Barudanović - Pilipović 2010:176). One of the most frequently reported strategies for dealing with food scarcity (both short and long term) was the gathering and consumption of wild plants (Huss-Ashmore - Johnston 1997: 83). Additionally, even items normally regarded as non-edible can be used to fill hungry stomachs. Overall, my fieldwork seems to suggest that extreme starvation and wartime conditions lead to loosening up of the generally practiced food exclusions and taboos. In other words, there are significant shifts in what is in Douglas' words 'good to eat' and what is not (see Douglas 2001). Also, Redžić et al. wrote that: 'People ate anything. Centuries long held myths about wild food, especially about mushrooms and lichens and some small animals, were disregarded' (Redžić - Barudanović - Pilipović 2010: 176). Moreover, Redžić (2010) emphasizes that semi-wild and wild plants were a precious source of nutrients in the Siege of Sarajevo and in other parts of Bosnia. Knowledge of older modes of cooking that rely more on self-sustainable production and local resources such as the use of dandelions or varieties of wild and semi-wild plants can play an invaluable role in terms of individual survival.

The shortage of flour, which is one the most important staples in the Bosnian diet, was a permanent feature for the entire duration of the armed conflict, even when the humanitarian aid started to come. During the existence of the SFRJ, flour had been mainly the matter of industrial production, however, in times of scarcity people developed strategies to produce it themselves. Old watermills were renovated or new ones were built and nearly everything that could be turned into flour was ground in them. ${ }^{5}$ Suljagić describes the situation as follows: After we had used up all the reserves of the white flour, we soon turned to grinding "black" [meaning integral], then corn flour and after that came oats, which could never be ground quite enough but tolerable, except that it was bitter and it slit and hurt our throats; even corncobs and hazel catkins were ground in the watermills' (Suljagić 2005: 41). This information was also confirmed by Armin, ${ }^{6}$ who also lived in Srebre-

5 Similarly, Beljak and Beljak (2014: 102) note that water mills were also renewed in Dalmatian rural areas.

6 In order to protect the privacy of my research participants I use pseudonyms. The selected parts of interviews cited in this dissertation contain minor stylistic 
nica during the war - he explained to me that hazel catkins were used to make flour and this was a common strategy of making substitute flour (Informal conversation Ibišević 2014). However, also my other research participants mentioned oats - they often referred to it pejoratively (according to some it was something that they would generally give to horses). Elvedin described the oat bread with the following words: 'When you ate a little piece of this bread it is the same as if thousands of needles got stuck in your teeth...' (Informal conversation Avdić 2018). Even though he was a child during the war, he remembers a lot of everyday details and also knows the life stories of his family and neighbours. Another important substitution of flour was a corncob. People tried to make pogača (a flat bread) from corncobs and apple syrup or water. However, this bread was hard to digest and as Elvedin says: 'When people went to the bathroom, they were crying' (Informal conversation Avdić 2018).

Perhaps the most important source of nutrition was mushrooms - in Podrinje a greater number of varieties of mushrooms were used in comparison to Sarajevo (Redžić - Barudanović - Pilipović 2010; Redžić 2010). A number of my research participants confirmed collecting wild mushrooms in the surrounding forests. ${ }^{7}$ Moreover, Redžić et al. mentioned that lichens were also used as an additive to flour and they were generally an important source of nutrition (Redžić - Barudanović - Pilipović 2010: 181-182). ${ }^{8}$ Lichens are fairly abundant in the area because of the clean air and they grow from summer to winter (ibidem: 181). Lichen products were important for both people and cattle (ibidem: 181). Lichens or lichenized fungi are generally first soaked in cold water over night and subsequently boiled in order to reduce the bitterness or acidity (ibidem: 181). They can be used in stews, soups, mashes or as additives to various meals (ibidem: 181). Redžić et al. emphasize that lichens were especially important in the winter when other foods were unavailable (ibidem: 182). Apart from their

changes, however, the meaning stays unchanged and is representative of the opinions of the interviewees. Also, as the vast majority of the interviews and informal conversations were carried out in Bosnian, some minor changes are the result of translation. The interviews were translated by the author.

7 The various types of fungi and plants haven't been botanically identified as I was carrying out research in the subdiscipline of sociocultural anthropology. This issue is going to be addressed in further research.

8 During my fieldwork I have not found people who claimed to consume lichens. However, this practice was reported in more remote areas in the Srebrenica municipality where I had carried out only little research as I worked mostly in the town and three selected villages. In any case, I presume that this wasn't dominant self-provisioning strategy (unlike in the case of mushrooms), nevertheless, the case is truly interesting and is worth mentioning. 
nutritive values, many lichens have medical properties and they can be used as prevention against many diseases because of their high anti-oxidant content (e.g. Cetraria islandica) (ibidem: 182). Even though lichens have lower nutritional value in comparison to mushrooms, they have high digestibility. None of my research participants consumed lichens during the war, however, some of them presume lichen to be edible. The reason for this can be determined by the average age difference in research samples; Redžić's sample included 51 persons (the majority of them above 50 years between 2004-2006) (ibidem: 178). Only several of my research participants belong to this age group.

Since Redžić's research in Podrinje was more focused on the use of mushrooms and fungi, it does not contain much information about other wild plants used for nutrition in this area (Redžić 2010). For illustration, I am going to also add information about the most commonly used wild plants which Redžić (2010) recorded in Sarajevo. In total, Redžić identified 91 species of wild and semi-wild plants and three species of fungus that were eaten during the siege of Sarajevo (ibidem). Some of the most frequently used semi-wild and wild plants during the Siege of Sarajevo were nettles, dandelions and coltsfoot (ibidem: 553-554). Nettles (but also coltsfoot) were often used to make pita zeljanica (Bosnian pie with leaf vegetables) or were simply cooked as a side dish, used as a beverage or condiment (see Redžić 2010: 560).

Coltsfoot leaves were also used for making sarma, but they served as tobacco as well if there was none (Redžić 2010: 560). Also, dandelion had multiple uses: the leaves would be again turned into a pie or they could be served fresh as a salad; the root could serve as a substitute for coffee and 'honey could be made' from the flowers (ibidem: 560-562). Another important substitute of coffee was the chicory root. As Redžić writes: 'Chicory root was picked during whole vegetation season. Dried in sun and fried was used for preparation of "war coffee". This is important, since coffee was unavailable in Sarajevo' (ibidem: 562).

Various wild plants were similarly used in Srebrenica to substitute ingredients that were unavailable. Most frequently mentioned wild plants are mushrooms, hazel catkins, nettles, patience dock, wild fruit and different herbs. Nettles, mushrooms and plants from the botanical genus rumex seem to be popular survival food in different armed conflicts. Apart from being important in the 1990s war in the Balkans (Redžić 2010; Redžić Barudanović - Pilipović 2010), the consumption of these species was also recorded in the Netherlands during the World War II (Vorstenbosch - de Zwarte - Duistermaat - van Andel 2017). One of the commonly reported strategies in other European wars was the consumption of beech nuts. 
Even though beeches are abundant in the Srebrenica area, the majority of my research participants did not hear of anyone consuming beech nuts. Nevertheless, after a closer investigation I have located one older person who claimed to have eaten beech nuts and acorns. Additionally, Redžić and Ferrier (2014) mention that at the end of 1992 Redžić called from the Centre for Assistance to Civilians in Sarajevo to the command post in Žepa to inform them about the possibility to use beech nuts, acorns and lichen as a substitute for flour. This further suggests that the consumption of beech nuts wasn't common in the area.

Overall, in Podrinje, including Srebrenica and Sarajevo, wild and semi-wild plants significantly decreased the risk of malnutrition and avitaminosis (Redžić - Barudanović - Pilipović 2010; Redžić 2010). Redžić et al. conclude with reference to other studies that the available nutritive diversity of wild mushrooms, lichens and plants made it possible to survive in the area of Podrinje without serious health consequences (Redžić - Barudanović Pilipović 2010: 184). The examples given above also show that the familiarity with subsistence agriculture, 'traditional' knowledge of the environment and the ability to improvise offer great advantages in the terms of survival.

\section{The UN Safe Area, Humanitarian Aid and the Use of Food as a Weapon}

While the majority of the civilians were surviving on very little, the armed groups of Srebrenica's militia (later on, some of them became soldiers officially) were slightly better off as they had the possibility to seize some of the VRS and 'Serb paramilitary' supplies, which included weapons and, most importantly, food. As I will show in the following section, food also came from village production in the area. The sources of food that remained were the ones of the above mentioned military formations linked to Belgrade and the villages where prevailingly persons of 'Bosnian Serb' origin lived as they were not affected by shelling and attacks by the JNA, VRS and other military groups and thus they could sustain agricultural production (see e.g. Suljagić 2005; Nuhanović 2015). It has been a well-known fact ever since the antiquity that the key to successful warfare and survival is access to food. Srebrenica's militias were also well-aware of this and they intentionally joined the mobs of hungry civilians on expeditions to the Bosnian Serb villages. This was an isolated opportunity for the people trapped in the enclave to obtain a more significant amount of food in an area controlled by the VRS. Cultivation of crops was nearly impossible as the target areas were exposed to heavy shelling (and other military operations) and controlled by snipers.

Likewise, Duijzings writes that since people were suffering from acute hunger, persons of Bosnian Muslim origin started to return to the villages 
in the surrounding area to search for food and they were joined by the numerous refugees from summer 1992 onward (Duijzings 2002: 124). These groups did not include only men, but also women and children who went to search for food - they were referred to as torbari (bag-people) (Duijzings 2002:124). The Serb forces attempted to prevent these groups from scavenging by organising ambushes and by laying mines in the countryside (ibidem: 124). Many were killed (ibidem: 124), however, the pressure of starvation was greater than the fear of losing life.

Srebrenica's militia was aware of the existence of torbari and thus groups of armed men at some point started to escort these civilians (Duijzings 2002: 128). Duijzings claims that the organized food raids were led by Naser Orić, Zulfo Tursunović, Akif Ustić and Hakija Meholjić (but Meholjić did not always participate) (ibidem: 128). Duijzings further notes that this proved an extremely effective tactic because the people of the Bosnian Serb/Orthodox origin, even though they were much better armed, could not defend themselves against these masses of desperate hungry persons (ibidem: 127).

Here Duijzings touches on an important controversy that many still argue about in the present - who precisely is 'a civilian'. I suggest that the majority of people in Srebrenica were civilians, as they were generally not armed, nor did they have proper military training or equipment. ${ }^{9}$ They did not want to get involved in fighting against armies - they were fighting for bare survival. When one lives on the verge of starvation, under shelling and 'face to face' with death, the mind seems to function differently and actions are to a large extent driven by the 'instinct' to survive (see Hasanović 2016; Nuhanović 2015; Nuhanović 2007; Suljagić 2005).

On the other hand, amongst the people there were also groups of armed militias whose primary interest was to protect these people and those who were involved in fighting. This needs to be taken into account. Yet, there is a big difference between this type of warfare and the state sanctioned violence, systematic torture and elimination and ethnic cleansing carried out by the professional armies of VRS and paramilitary groups under the leadership of Radovan Karadžić and Ratko Mladić and the support of Slobodan Milošević (for the interrelation between these people with the military operations see e.g. Honig - Both 1997; Duijzings 2002).

Besieging the cities was not the only strategy for starving out populations applied by the JNA and VRS. Nele from the village of Klotjevac mentioned

9 Adult men generally went through the compulsory army service during the SFRJ, however, they were not professional soldiers and, thus, had only very limited warfare skills. Some of the civilians had hunting rifles since the area was very famous for hunting during the socialism. Again, this is not a professional military equipment and cannot be compared to heavy artillery etc. 
that they were intentionally shelling the crops that he had managed to grow in wartime (Interview Mehić 2015). As he was hiding inside his house in order not to get hit, he watched his crop burn (Interview Mehić 2015). He said that they also targeted the cattle: 'It's a terrible sound listening to the cattle scream when it's being burnt alive' (Interview Mehić 2015). The described situation also shows that food or, more precisely, the lack of it can be used as a tool of control and/or an attempt to 'wipe out' entire targeted populations. As Collinson and Macbeth have argued the intentional restriction of food by either of the sides of conflict is a 'weapon of war' (Collinson - Macbeth 2014: 2). Concentrating and besieging the targeted populations is one of the mechanisms of eventually starving them out. Ultimately, those who are denied access to food can use violent behaviour towards those who deny them access to it who are thus defined as the oppressor.

One of the most serious issues in the enclave was the lack of salt. Suljagić writes that this was a problem already in 1992, but the situation persisted even after Srebrenica became the UN 'Safe Area' (Suljagić 2005: 61). He claims that every convoy which was supposed to bring the promised salt was turned back by the VRS (ibidem: 61). Salt was sold on the black market but its price rose to 50 German Marks per kg (ibidem: 61). Therefore, it was unavailable for the impoverished starving populations. People even tried to collect the 'black' unrefined salt that was used for salting roads and cook it over and over (see ibidem: 61-62). Here it should be mentioned that salt deficiency (hyponatremia) leads to serious health issues and results in seizures and coma (The Free Dictionary by Farlex, Medical Dictionary, Salt Deficiency).

A few weeks before Srebrenica was pronounced a Safe Area on February 19, 1993 the UNHCR (The UN Refugee Agency) report describes the situation in town as follows: 'According to our findings there is no food in the city. The inhabitants haven't eaten properly for months and they are living on wheat husks and roots, so many of them die from hunger and exhaustion' (Honig - Both 1997: 106). Not long after that, at the beginning of March 1993, Supreme Commander of the UN forces in Bosnia and Herzegovina, General Philippe Morillon, arrived in Srebrenica (Honig - Both 1997: 109-113; Hasanović 2016: 41; Suljagić 2005: 41). Suljagić (2005: 41) remarks that during the visit Morillon was offered bread made out of hazel catkins to show him what people trapped in the enclave survived on. Suljagić said Morillon looked a little bit ashamed as he answered: 'It's healthy and good for digestion' (Suljagić 2005: 41).

On April 16, 1993, Srebrenica was officially pronounced the 'UN Safe Area' by the United Nations Security Council Resolution 819 (see Honig Both 1997: 127). Honig and Both (1997: 128) claim that this was confusing 
for UNPROFOR (the United Nations Protection Force) itself, therefore Generals Morillon and Wahlgren organised a meeting with General Mladić (VRS) and General Halilović (ARBiH/Army of the Republic of Bosnia and Herzegovina). In the end they agreed that a Canadian peace force would be able to enter Srebrenica and help to demilitarise the zone and also 500 heavily wounded people could be evacuated by helicopter (ibidem: 128-129). After not even a year, at the beginning of March 1994, the Canadian UNPROFOR soldiers were replaced by a Dutch Battalion (Air Mobile Brigade of the Royal Netherlands Armed Forces) which consisted of about 570 men (ibidem: 153).

Under the UN protection, the reason for the severe malnourishment of the persons in the enclave was very much a result of checks and confiscation of food by the VRS. As Honig and Both (1997: 153-154) write, the humanitarian convoys were often stopped, searched and frequently returned. The VRS were making sure that there was only a bare minimum of supplies reaching the enclave since they were well aware of the fact that a modern army cannot function without them (ibidem: 153-154). From time to time, the VRS would also hold the Dutch soldiers as hostage to scare them and also to prevent NATO airstrikes (ibidem: 153-154). As a result, it was commonly accepted that the VRS would take part of the supplies from food convoys. Also, a former Dutch soldier Tim confirmed that the VRS would commonly stop the convoys and UNHCR vehicles and take half of the supplies (Interview Jansen 2014). The VRS would often argue that the UN did not have proper clearance even if they did (Interview Jansen 2014). They would take medications, diesel and everything else they needed (Interview Jansen 2014). 'If Serbs said no food, there was no food,' Tim remarked (Interview Jansen 2014). He said that when he came at the beginning of 1995, he believed that the UN would help them, but he was part of a convoy which was stopped by the VRS and to his surprise the responsible UN commanders told him to let them take what they wanted (Interview Jansen 2014).

Bill Clinton (president of the US at the time) suggested airdrops in order to resolve the convoy issue, thus from March to June 1993 about 1900 tons of food and medicine were dropped around Srebrenica (Honig - Both 1997: 106). However, the UN saw the operation as possibly problematic since it was giving the VRS a sign that Washington wanted to stay away (ibidem: 106). On an everyday basis, the airdrops had other problems that are not generally discussed. The airdrops were likely to be wasted if the parachute did not open, which supposedly happened quite frequently. They were inconvenient for the receivers as they were thrown at night into surroundings that were hard to reach. Moreover, it was never certain where the aid was going to land and thus could be potentially life endangering. In his 
memoirs Hasanović points out to these problems and describes how he saw a 16-year-old boy a few meters from him being killed by a humanitarian aid cargo of food (Hasanović 2016: 38-39).

Honig and Both emphasise that, several months before the Fall of Srebrenica in July 1995, not even the Dutch soldiers were getting enough supplies for themselves, because food and diesel were being confiscated (Honig - Both 1997: 159-160). At the beginning of June 1995, a doctor from one of the battalions even writes an alarming report about the state of health of the soldiers (ibidem: 160). Tim, who was serving in Dutchbat III under the command of Lieutenant Colonel Thomas Karremans. Tim said that they did not really have enough food for themselves several months before the fall (Interview Jansen 2014). He said that in the last 3 or 4 months of his tour he lost about $15 \mathrm{~kg}$ and also his colleagues were weak and did not have the strength to do the job (Interview Jansen 2014). Tim said that in the period when there were no convoys, they would only get cans and he especially hated the ones containing ravioli (Interview Jansen 2014).

Thus, despite UN protection, the living conditions in the enclave did not improve much. One of the main reasons for this was the intentional blocking and confiscating of the humanitarian aid by the VRS (Honig - Both 1997), as well as the nature of the humanitarian aid itself (Redžić 2010). Cathie Carmichael mentions a British officer, Garry Donaldson, who visited Srebrenica before the genocide in 1995 (Carmichael 2003). Carmichael writes: 'He was reminded of the Warsaw ghetto: the quiet hungry eyes of the children crouching around the food distribution points, the vulnerable old men and women pushed to the back of the queue by the strongest, the figures combing the rubbish dump for food. He, like many of the foreign observers, was numbed by his inability to prevent this humanitarian disaster. He could only think "the sadness of the poverty and deprivation was overwhelming".' (Carmichael 2003: 84)

Tim, the former Dutchbat III soldier, mentioned that people from the enclave would come to the fence of the UN Dutchbat hoping to get something (Interview Jansen 2014). Especially children would follow them around. He said: 'If I had something to eat - here and there a convoy or I got a package from my parents, family or friends and when there was some food in it like chocolate... I gave it to children... For example yellow M\&Ms...When we walked around the surrounding area, the children were always following us and called: Mr. Bonbon, Mr. Bonbon... I had small pack of MEM, so I gave one to each child. The next time the children come back to the fence they call: Mister, look, I still have it! ... At home in Holland, try that. When I give to my son a pack of yellow MEMM, he's eight now, the bag is empty in ten seconds. And here: Mister 
look, I still have it... I have to tell them, eat it, tomorrow you will get another one. Eat it!' (Interview Jansen 2014) ${ }^{10}$

Tim also spoke about how desperate the people trapped in the enclave were. With a disturbed look in his face, he stated: 'If I wanted, but I didn't do it, I could have a Bosnian girl at the time for one bag of sugar... You know the small one' (Interview Jansen 2014). 'That really happened?' I asked. 'Yes, it happened,' Tim uttered and continued explaining: 'Fathers and brothers came to the fence and they brought their daughters and sister and asked through the fence: Do you want her:"11 It will cost you sugar, salt or something similar. In those days people would do anything because of food. It happened but I didn't do it. Everything I had, I gave away... Here food had an invaluable price. It was like gold.' (Interview Jansen 2014)

\section{Conclusion: Halva evokes memories of the dead}

In the late 20th century, Srebrenica and its close surroundings constituted one of the well-developed localities of the SFRJ, mainly due to its long history of metal industry, spa tourism and attractive countryside (see e.g. Salimović 2002). This privileged position drastically changed in the last armed conflict during the first half of the 1990s when Srebrenica became an isolated enclave under the siege - a place where thousands of Bosnians and other minorities from adjoining areas of Podrinje sought refuge. As Halilovich notes, one of the many of the refugee groups that came to Srebrenica included for example the inhabitants of the village of Klotjevac (Halilovich 2015: 37). This situation was a result of systematic ethnic cleansing which Honig and Both identify as one of the characteristics of the war (Honig - Both 1997: 101). Similarly to numerous other authors, Carmichael (2003) argues that the term ethnic cleansing is appropriate to describe the series of events that took place during the last conflict in the Balkans. Moreover, based on my fieldwork findings and the material provided by the International Commission on Missing Persons (ICMP), I support the International Criminal Tribunal for the Former Yugoslavia at the Hague (ICTY) verdict that defines the events as an act of genocide. For further arguments concerning this matter see Halilovich (2015: 39-41). For definition of genocide see e.g. Zwaan (2003).

10 Also, Honig and Both mentioned that the children called the soldier Mister Bon Bon (see Honig - Both 1997: 157)

11 The information that the brothers and fathers brought their female relatives to the fence is not confirmed by other sources. Therefore, I would treat this information rather carefully, it might be a misunderstanding of the research participant. On the other hand, the appearance of sex trade and rape was reported by other research participants and researchers. 
In the particular case of the area of Podrinje, military operations were carried out first by the JNA, which operated from Belgrade, Serbia (Halilovich 2015), the VRS (Honig - Both 1997), and various paramilitary groups (Duijzings 2002: 102). At the beginning, operations were carried out by the JNA, which was disbanded on May 20,1992 and then the operations in $\mathrm{BiH}$ were officially run by the VRS. The VRS was officially created on June 1, 1992 (see ICTY, Judgment Prosecutor vs. Momčilo Krajišnik 2006: 72). However, both the weapons and the soldiers for creating the VRS were supplied by the JNA which was controlled from contemporary Serbia (at that point part of the Savezna Republika fugoslavija - the Federal Republic of Yugoslavia). This is also the reason why some authors use multiple titles to describe the armies or the countries. It is also important to note that in the area of Podrinje persecution was not aimed only at people of Bosnian Muslim origin but at all non-Serb inhabitants of the region. The grave of Rudolf (a Bosnian Catholic Christian) who was killed during the last war while helping to defend Srebrenica along with the others serves as an example of this. Today, his grave is the only non-Muslim grave at the Memorial Cemetery in Potočari. Duijzings, with reference to Ivanišević, mentions that local Roma from Kazani (part of Srebrenica) were, according to the testimonies, present during some of the fighting (Duijzings 2002: 125). Additionally, Hasanović mentions his Roma neighbours in his memoir Surviving Srebrenica (Hasanović 2016: 32).

In July 1995, the town suffered a heavy military offensive conducted by the VRS (Honig - Both 1997: 22-92). Srebrenica fell in the afternoon on July 11, 1995 (ibidem: 52). After the defeat of the town, Ratko Mladić made a statement for the television saying that the moment of revenge against the 'Turks' had finally come and that Srebrenica was now 'Serbian' - it was a gift to the 'Serbian nation' (see Carmichael 2003: 33-34). Once the town had fallen into the hands of VRS, deportations of the refugees followed and at the same time several thousands of men unsuccessfully attempted to escape through the forest (see Honig - Both 1997: 53-92) but many were killed by the VRS.

The massacre of the men and boys of prevailingly Bosnian Muslim origin has been well described (see Honig - Both 1997: 53-92). The Report on the Number of Missing and Dead from Srebrenica offered by ICTY summarises these tragic events as follows: 'When the enclave of Srebrenica fell on 11 July 1995 a number of men tried to escape by walking through the forest, and many of them were killed on the way or after surrendering or being captured. Others were separated from their families in Potočari and later executed. Several women, children and old men were also killed' (Brunborg - Urdal 2000: 1). Analysis of the mass graves exhumations, demographic expertise and the 
testimonies of the victims and the accused led the ICTY to the conclusion that approximately between 11 and 19 July 1995 the Bosnian-Serb Army (VRS) and other forces executed between 7,000 and 8,000 civilians or prisoners of the war (POW) - the majority of them were men and boys of Bosnian Muslim origin (ICTY, Facts about Srebrenica). ${ }^{12}$ According to the findings of ICTY, the massacre and subsequent cover-up operations were planned and well organised and this is precisely the reason why the act was classified as a genocide (ICTY, Facts about Srebrenica).

Furthermore, I argue that the people concentrated in the UN 'Safe Area' Srebrenica were intentionally subjected to mass starvation prior to the genocide (Slavková 2017). One of the most commonly adopted strategies against the food insecurity was food self-provisioning along with improvisation concerning the utilisation of the humanitarian aid as well as the consumption of wild and semi-wild plants (Slavková 2017). Overall, I attempted to show that the bio-cultural knowledge of food self-sufficiency plays an important role in increasing the individual survival chance in times of overall material scarcity and starvation.

At the end of July 2014, I was helping Nura with the preparations for Bajram..$^{13}$ I was mostly preoccupied with cooking. We prepared many dishes such as bread, sarma, pita and baklava (Participant observation Selimović 2014). However, a particular type of halva caught my attention during that Bajram. Nura made semolina halva which is a sweet dish of oriental origin that generally consists of flour, butter/margarine, sugar, water and nuts. Flour is roasted with fat on a pan and when the mixture turns golden, hot sugar syrup (agda) is added. The ingredients form a flexible ball which is divided by spoon into small servings and decorated with nuts. It is moderate in appearance, but it smells sweet and seductive. Nura commented that when the aroma of halva lingers in the room, it is the 'real Bajram' (Participant observation Selimović 2014).

The festival and the preparation and consumption of certain foods invoked memories. It was in that context when Nura and other family members spoke more frequently about the war and the ones they had lost. At one point, Nura also mentioned that they say that halva attracts the souls

12 Estimations of the numbers of victims of Srebrenica genocide differ and are in a certain sense a controversy. I use the information given by the ICTY. However, the number of victims might be higher. Based on my research findings I refuse the speculations that the number of the dead is much lower than what has been stated by ICTY and ICMP.

13 Bajram is an expression used in $\mathrm{BiH}$ for one of the most important religious holidays in Islam. There are two Bajrams: Ramadan Bajram and Kurban Bajram ('Feast of sacrifice' in Arabic Eid al-Adha). 
of the dead (Participant observation Selimović 2014). ${ }^{14}$ This remark made me shiver a little: only the day before she had spoken to me for the first time about having lost her husband.

Nura and her family live in a house at the very end of the southern part of the city. This is also the direction from which the VRS, led by Ratko Mladić, entered the city. When it was clear that the town was defeated, she and her mother Ramiza took all five children and they went to seek refuge in Potočari like the other remaining civilians in the town. Nura was only in her early thirties. Her youngest children, the twins, were about two months old. They had to carry them in their arms. The distance that they had to walk was about $8 \mathrm{~km}$. They sought refuge at the UN Dutch Base (a former battery factory) from where they were later deported to a refugee camp. During those days Nura's husband, father of five children, was killed by the VRS.

Time passed by and Nura's husband did not come back. They were waiting and hoping. However, when the first mass graves were discovered, Nura lost all hope. Around that time the ICMP (International Commission on Missing Persons) introduced a DNA-based identification program which had been developed for these purposes. They refused to believe that he was dead until 2007, when his remains were identified. Azra, the oldest daughter, writes in her autobiography that the painful years of wartime and especially her father's death took away her childhood and she lost any sense of home. She is never going to feel the same in Srebrenica again.

She wrote: 'Some, like my father, stayed in the woods. They've become shehids ${ }^{15}$ - meat, food for animals and the victims of the savages. Srebrenica is now barren and horrible. Everything got fucked up. My pine trees are no more, some people burned them, cut them, took them away, they took my little childhood house, which I once really liked and cared for. Now it only exists in my heart, without the pine trees, branches; there are no traces that it ever existed. There is no more green, big meadow, where we played as children. It turned into the forest, ferns and thorns. I stopped believing that it ever existed...' (Autobiography Selimović 2014)

By writing these lines Azra expresses the despair and profound emptiness caused by the 1990s war. The loss of the people and the destruction of the community which used to constitute her home is permanent. She uses

14 This belief is probably linked to the beliefs common in Turkey. Dr. Ayşe Çağlar Univ.-Prof. explained to me that in Turkey the semolina halva is known also as 'halva of the dead'. Its preparation is part of the funeral rite. However, this is not practiced in $\mathrm{BiH}$, but the belief that 'the souls of the dead' are attracted by the smell of halva is probably related.

15 Shehid or šehid (in Bosnian) is literally 'martyr', however, in Bosnia this term is used for all the victims of Bosnian Muslim origin who died in the 1992-1995 war, whether they were religious or not. 
a powerful food metaphor to describe the internal horrors that she experiences, when she imagines the bodies of the dead to be eaten in the forest by animals. Here we clearly see the different ways in which the memories are infused with social meanings and entangled with emotions and how they enter the domain of food. Overall, I conclude that the lack of food during the war is recollected both in Srebrenica and Sarajevo with an emotional 'charge'. The narratives of hunger during the war underline emotions of displeasure such as: sadness, anxiety, disgust, resentment, and anger.

The aim of this article was to explore the role of consumption practices and various discourses concerning the food domain in relation to armed conflicts and post-conflict 'reconstruction' in Srebrenica in the context of the 1990s war. Eating practices are generally resilient to change (Mintz 1995). War is an exception, as it constitutes a major social rupture that creates an opening for a new food or nutrition pattern and at the same time it is a reason for abandoning the old (Mintz 1995; Messer 1997). This is mainly due to the destabilisation of food production systems, which typically arises in armed conflicts. The collapse of infrastructure results in overall material scarcity and leaves the affected populations hungry. Nevertheless, in some situations the starvation is caused by intentional acts by particular social actors and groups. The former 'UN Safe Area' Srebrenica can unfortunately serve as an example of the latter case. As I attempted to show in this article, the populations targeted on the basis of their ascribed identity were systematically starved out prior to the Srebrenica genocide in 1995.

June 2019

\section{References}

Brunborg, Helge - Urdal, Henrik. 2000. The Report on the Number of Missing and Dead from Srebrenica. International Criminal Tribunal for the Former Yugoslavia. [Online] [2019-02-13] Retrieved from: http://www. icty.org/x/file/About/OTP/War_Demographics/en/krstic_srebrenica_000212.pdf.

Beljak, Nives Rittig - Beljak, Bruno. 2014. The Logic of War and Wartime Meals. In: Collinson, Paul - Macbeth, Helen (eds.): Food in Zones of Conflict: Cross-Disciplinary Perspectives. New York - Oxford: Berghahn: 95-105.

Carmichael, Cathie. 2003. Ethnic Cleansing in the Balkans: Nationalism and the Destruction of Tradition. London - New York: Routledge. This edition published by Taylor \& Francis e-Library. 
Collingham, Lizzie. 2012. The Taste of War: World War Troo and the Battle for Food. United Kingdom: Penguin Books.

Collinson, Paul - Macbeth, Helen (eds.). 2014. Food in Zones of Conflict: Cross-Disciplinary Perspectives. New York - Oxford: Berghahn.

Duijzings, Ger. 2002. Srebrenica: A 'Safe' Area, Appendix IV, History and Reminders in East Bosnia. In: Netherlands Institute for War Documentation. [2019-02-13] Retrieved from: https://www. niod.nl/sites/niod.nl/files/G.\%20Duijzings\%20-\%20Geschiedenis\%20en\%20herinnering\%20in\%20Oost-Bosnië.\%20De\%20achtergronden\%20van\%20de\%20val\%20van\%20Srebrenica\%20-\%20 Engels.pdf.

Douglas, Mary. 2001. Purity and Danger. An Analysis of the Concepts of Pollution and Taboo. London - New York: Routledge. This edition published by Taylor \& Francis e-Library.

Facts about Srebrenica. International Criminal Tribunal for the Former Yugoslavia. [Online] [2019-02-13] Retrieved from: http://www.icty. org/x/file/Outreach/view_from_hague/jit_srebrenica_en.pdf.

Halilovich, Hariz. 2015. Places of Pain: Forced Displacement, Popular Memory and Trans-local Identities in Bosnian War-torn Communities. New York - Oxford: Berghahn Books.

Hasanović, Hasan. 2016. Surviving Srebrenica. United Kingdom: Lumphanan Press.

Honig, Jan W. - Both, Norbert. 1997. Srebrenica - Hronika ratnog zločina. Sarajevo: Ljiljan.

Huss-Ashmore, Rebecca - Johnston, Susan L. 1997. Wild Plants as Famine Foods: Food Choice Under Conditions of Scarcity. In: Macbeth, Helen (ed.): Food Preferences and Taste: Continuity and Change. Providence - Oxford: Berghahn Books: 83-100.

International Tribunal for the Prosecution of Persons Responsible for Serious Violations of International Humanitarian Law Committed in the Territory of the Former Yugoslavia since 1991. 2006. Prosecutor vs. Momčilo Krajišnik. Judgement. Case: IT-00-39-T. Date: 27 September 2006.

Jug-Dujaković, Marija - Łuczaj, Łukasz. 2016. The Contribution of Josip Bakić's Research to the Study of Wild Edible Plants of the Adriatic Coast: A Military Project with Ethnobiological and Anthropological Implications. Slovak Ethnology/Slovenský národopis 64, 2: 158-168.

Messer, Ellen. 1997. Three centuries of Changing European Tastes for the Potato. In: Macbeth, Helen (ed.): Food Preferences and Taste: Continuity and Change. Providence - Oxford: Berghahn Books: 101-113. 
Mintz, Sidney. 1995. Food and Its Relationship to Concepts of Power. In: McMichael, Philip (ed.): Food and Agrarian Orders in the World-Economy. United States of America: Greenwood Press: 3-13.

Nuhanović, Hasan. 2007. Under the UN Flag: the International Community and the Srebrenica Genocide. Sarajevo: DES Sarajevo.

Nuhanović, Hasan. 2015. Zbijeg - Put u Srebrenicu. Sarajevo: Centar za napredne studije.

Redžić, Sulejman. 2010. Use of Wild and Semi-Wild Edible Plants in Nutrition and Survival of People in 1430 Days of Siege of Sarajevo during the War in Bosnia and Herzegovina (1992-1995). Collegium Anthropologicum 34, 2: 551-570.

Redžić, Sulejman - Barudanović, Senka - Pilipović, Saša. 2010. Wild Mushrooms and Lichens used as Human Food for Survival in War Conditions. Podrinje - Zepa Region (Bosnia and Herzegovina, W. Balkan). Human Ecology Review 17, 2: 175-187.

Redžić, Sulejman - Ferrier, Jonathan. 2014. The Use of Wild Plants for Human Nutrition During a War: Eastern Bosnia (Western Balkans). In: Pieroni, Andrea - Quave, Cassandra L. (eds.): Ethnobotany and Biocultural Diversities in the Balkans: Perspectives on Sustainable Rural Development and Reconciliation. New York: Springer-Verlag: 149-182.

Salimović, Sadik. 2002. Knjiga o Srebrenici. Srebrenica: Skupština Opštine Srebrenica.

Slavková, Markéta. 2017. Cooking and Dining in Times of War and Peace: Changing Contexts and Modes of Food Production, Preparation and Consumption in Srebrenica, Bosnia and Herzegovina. PhD dissertation. Praha: Univerzita Karlova.

Suljagić, Emir. 2005. Razglednica iz groba. Zagreb: Durieux.

The Free Dictionary by Farlex, Medical Dictionary, Salt deficiency. 2012. Farlex Partner Medical Dictionary. [Online] [2019-02-13] Retrieved from: http://medical-dictionary.thefreedictionary.com/ Salt+deficiency.

Vorstenbosch, Tom - de Zwarte, Ingrid - Duistermaat, Leni - van Andel, Tinde. 2017. Famine Food of Vegetal Origin Consumed in the Netherlands during World War II. Journal of Ethnobiology and Ethnomedicine 13: 63. [2019-02-13] Retrieved from: https://www.ncbi.nlm.nih. gov/pmc/articles/PMC5693569/.

Zwaan, Ton. 2003. On the Aetiology and Genesis of Genocides and other Mass Crimes - Targeting Specific Groups. Amsterdam: Centre for Holocaust and Genocide Studies, University of Amsterdam. 


\section{Participant observation and interview}

Avdić, Elvedin (pseudonym). 2018. Informal conversation. Born 1986, survivor of Srebrenica genocide, self-employed. Field notes held by the author.

Ibišević, Armin (pseudonym). 2014. Informal conversation and interview. Born 1979, survivor of Srebrenica genocide, postman. Oral testimony. Audio recording held by the author.

Mehić, Nele (pseudonym). 2015. Interview. Date of birth unknown (approx. 60 years old), survivor of Srebrenica genocide, farmer in Klotjevac. Oral testimony. Audio recording held by the author. Jansen, Tim (pseudonym). 2014. Interview. Date of birth unknown (approx. in the mid-40s), former Dutchbat III soldier in Srebrenica. Oral testimony. Audio recording held by the author.

Selimović, Azra (pseudonym). 2014. Autobiography. Born 1986, survivor of Srebrenica genocide, currently on maternity leave. Unpublished autobiography. Copy held by the author.

Selimović, Nura (pseudonym). 2014. Participant observation. Born approx. 1963, survivor of Srebrenica genocide, widow. Participant observation. Field notes held by the author. 